\begin{tabular}{|c|c|}
\hline \multirow[t]{3}{*}{ ISSN 1407-7493 } & $\begin{array}{c}\text { DATORZINĀTNE } \\
\text { COMPUTER SCIENCE }\end{array}$ \\
\hline & $\begin{array}{l}\text { INFORMATION TECHNOLOGY AND } \\
\text { MANAGEMENT SCIENCE }\end{array}$ \\
\hline & $\begin{array}{c}\text { INFORMĀCIJAS TEHNOLOĢIJA UN } \\
\text { VADĪBAS ZINĀTNE }\end{array}$ \\
\hline
\end{tabular}

\title{
FUNCTIONAL MANAGEMENT OF ECONOMY
}

\section{EKONOMIKAS FUNKCIONĀLĀ VADĪBA}

Aloizs Ratnieks is currently lecturer in the Department of Applied Computer Systems at Riga Technical University. He received his master's degree in Applied Computer Science from Riga Technical University in 1994. His research interests include numerical methods, Fermat's theorem and functional management. 


\begin{abstract}
This paper discusses the unknown before property of adapting systems which consists in that the adapting system may be operated without any information about its condition. It is necessary to know only some characteristics of its elements. It was found, however, that the economic methods of management have limited possibilities, it is impossible to regulate with their help all those parameters which are not involved in the process of exchange. Another, more universal, economic management method is provided. The economic method of management discussed in the paper enables one to separate the management of economy from labour-management relations and to expand the application field of mathematics in the field of management. The provided management method gives opportunity to get rid of centuries old bureaucracy because it enables one to substitute the considerable part of administrative - bureaucratic apparatus as well as many standard acts with one functional relationship.
\end{abstract}

\section{Introduction}

All existing methods of the administration in economy are far from being ideal. The absence of mutuallyunambiguous correspondence between the results of the work of citizens and the reward received for their work is the confirmation of this fact. The slowing down of development tempo, periodic collapses of world's currencies and the world economics crisis are connected with great shortcomings in the system of regulation. The necessity to improve the management system of economy has become evident event for non-specialists. Moreover, great hopes are set on market, privatisation and economic methods of management.

The economic methods of management, however, have limited possibilities. It is impossible to regulate with their help all those parameters which are not involved in the process of exchange. To such parameters belong, for example, the rate of labour resources employment, price level on goods, range of wages etc. To control such parameters, it is desirable to find another, more universal method of management, a particular case of which would be economic methods of management. Such more universal control method is functional control, discovered by the author.

The control processes in different systems are studied by cybernetics. A generally accepted point of view in cybernetics is that for control of a complex system it is necessary to know the information about its condition. The known principles of control systems functioning required the creation of special systems collecting and processing information, reliable communication channels with big capacity and powerful controlling means.

To shorten the control system repayment period as well as to reduce costs for its creation it was recommended by academician V.A. Trapesnikov to avoid, for example, excessive "detailing" of used information [1]. However while applying the known principles of control systems functioning, this practice results in reduction of control effectiveness.

\section{Functional Control}

The author refutes the generally accepted point of view that for control of a complicated system it is necessary to know the information about its condition. The unknown before property of adapting systems is found out which consists in that the adapting system may be operated without any information about its condition. It is necessary to know only some characteristics of its elements. In economic system, for example, as such characteristics may be used the tendency of its elements to create material and psychological comfort.

Let us consider as an example the scheme of economic system functional control illustrated in Fig. 1.

If no limitations are imposed on the number of variables in the controlling function $\mathrm{z}(\mathrm{x}, \mathrm{y})$, then there is a possibility of selecting the controlling function so that the material and psychological comfort of those system elements which act to achieve the goal of administration would increase and accordingly decrease for those system elements whose actions run counter to the goal of administration.

Since elements of the economic system have tendency to create material and psychological comfort, their actions will be directed to the attainment of control goal. Consequently, the control with the help of functional dependencies is very effective. 


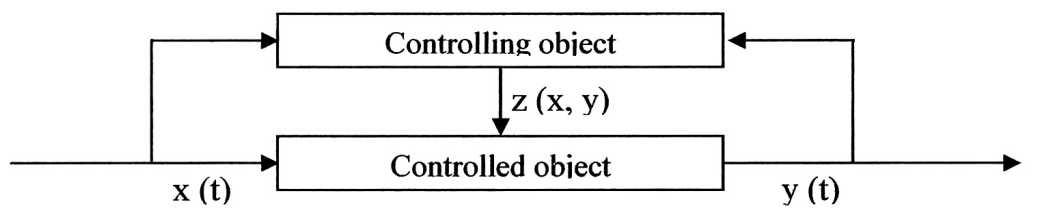

$x(t)$ - material resources used in the production process;

$y(t)$ - final product, received as a result of production;

$z(x, y)$ - controlling function.

Fig. 1. The scheme of economic system functional control

Since for assigning the control function $\mathrm{z}(\mathrm{x}, \mathrm{y})$ there is no need to know information about the system condition (concrete values of functions $x(t)$ and $y(t))$, it is possible to control the adapting system without any information about its condition.

Functional control is widely spread in nature. While putting on light clothes in summer and sheepskin in winter, we even do not think about the fact that functional dependence of environmental temperature on season controls our behaviour.

The principle of adapting systems control, discovered by the author, has a number of striking peculiarities. Let us consider some of them.

First, it is possible to control only those parameters which can be expressed in $\mathrm{x}(\mathrm{t})$ and $\mathrm{y}(\mathrm{t})$. In economic system to such parameters belong only those parameters which participate in the process of exchange (economic parameters).

Secondly, the functional approach may be effectively used also for control of those parameters which do not participate in the process of exchange. However to control such parameters it is necessary to know the information about the condition of a system.

Thirdly, as distinguished from all known control systems where each system entrance is provided with only one value of function (the signal in the form of electric field potential or other physical value) in case of functional control the functional dependencies are used "completely", because the elements of the system produce the strategy of their behaviour on the basis of behaviour analysis of the whole controlling function.

Fourthly, in case of application of the functional approach, the feedback has purely informational character, and may be present and absent simultaneously.

Finally, as the number of parameters being regulated is not great, even in such complicated systems as economic ones, it is possible then to use quite simple functions for administration.

Academician A.I. Khuhtenko noted that it has already passed more than 10 years since it became evident for many specialists that theory of automatic control suffers crisis. It is true that mathematical research methods of different dynamic properties of systems, usually described with the language of differential equations which were developed in the theory of automatic control in many cases cannot be used for solving all those numerous problems which are met in life and set up by practice of modern technology, economics, biology, physiology, sociology development. But all those problems are related to the range of problems rightfully called the problems of control [2].

Due to the discovery of functional approach, the way out of the above-mentioned crisis was found which resulted from the fact that the control style well recommended by control of systems with small information volume had been spread on the systems with very big information volume.

The governmental regulation of economy has always resulted in the appearance of corruption. The functional administration is free from such shortcoming as it enables one to separate the management of economy from labourmanagement relations. Assigning the controlling actions in the form of functional relationships enables to create such social system of market type which can combine the advantages of socialism and capitalism and does not have their faults. It will also make impossible plunging of politicians form one extreme to another, the working people being without legal rights all the time.

It is a well known fact that taxation systems in many countries, the USA for example, are incredibly complicated and unjust. They require tremendous staff apparatus and cannot exist without computers. It is hard to find a person in the West that is satisfied with the taxation system of his country. Applying functional administration, the state can fully abolish charging of taxes and concentrate profit in those spheres which give the biggest output.

Let us consider the simplest example of functional control. Let the average wage level in a factory be given in the form of function (1):

$$
S=C-D \cdot e^{-B P / Q}
$$

where

$\mathrm{S}$ - average wage level; 
$\mathrm{C}$ - maximum wage level;

$\mathrm{D}$ - range of wage changes;

e -the number which equals approximately to 2.71 ;

B -coefficient for regulation of employment of labour resources;

$\mathrm{P}$ - specific surplus product which can be accounted according to the formula (2);

Q - average value of specific surplus product for given industry branch.

$$
P=\frac{k_{1} F-M-k_{2} Z-k_{3} U}{N}
$$

where

$\mathrm{F}$ - cost of finished product;

$\mathrm{M}-$ cost of resources used in the production process of the finished product;

$\mathrm{Z}$ - cost of non-realized production (or cost of circulating funds);

$\mathrm{U}$ - direct or indirect damage caused to a contractor because of contract violation;

$\mathrm{N}$ - number of workers in a factory;

$$
\mathrm{K}_{1}, \mathrm{~K}_{2}, \mathrm{~K}_{3} \text { - coefficients. }
$$

Fig. 2 shows the graph of this function.

It is then possible with the help of variable $\mathrm{C}$ to regulate maximum wage level, with the help of variable $\mathrm{D}$ - the minimum wage level, with the help of coefficient B - rate of labour resources employment; with the help of coefficient $\mathrm{K}_{1}$ it is possible to regulate the balance of population solvent demand with the goods supply, with the help of the coefficient $\mathrm{K}_{2}$ it is possible to regulate the volume of not realized production or turnover assets, by means of coefficient $\mathrm{K}_{3}$ - rate of sanctions for non-fulfilment of a plan or contract violation.

The regulation of labour resources employment is based on the contradiction between material and psychological comfort. Providing psychological comfort inevitably results in the necessity to give up some part of material comfort. At large values of coefficient $\mathrm{B}$ the average wage of workers is close to the value of variable $\mathrm{C}$ that is why for providing psychological comfort it is advantageous for collective to increase the quantity of workers. At small values of coefficient $B$ the average wage of workers increases when the number of workers decreases, therefore it is profitable for workers' collective to reduce the number of workers for providing material comfort. The values of variables $B, C$ and $D$ should be specially selected in order to exclude unemployment, deficit of labour force and social inequality of society's members. The social justice and health are defined not by possession of production means but rather by a rational distribution of produced goods between the numbers of society. The regulation principles of other parameters are evident and do not require any additional explanations.

After computing the average wage, it is possible to define the wage of each worker with the help of optimal scale. The exponential function, shown in Fig. 3 may be used for that purpose. The parameters of this function are calculated according to average earning, the number of workers at the enterprise and minimal level of earning.

Fig. 3 is based on the assumption that the first worker has the highest position and qualification.

Functional control doesn't limit the workers' initiative, it enables one to put an end to poverty and to put an end to despotism of officials and to do away with indistinctness, vagueness of laws; it also helps to raise business activity of workers.

Brigade methods of labour organization, cost accounting and lease introduced before were the simplest forms of functional control.

\section{Conclusions}

The unknown before property of adapting systems is found out that can be stated as follows: the adapting system may be operated without any information about its condition. It enabled finding another, more universal method of control, a particular case of which would be economic methods of management.

Since all the defined properties of adapting systems fully met all requirements to scientific discoveries imposed by legislation of the former USSR, two patent applications were registered by the author, which were sent to the state Committee of Discoveries and Inventions in 1976 and 1979 accordingly.

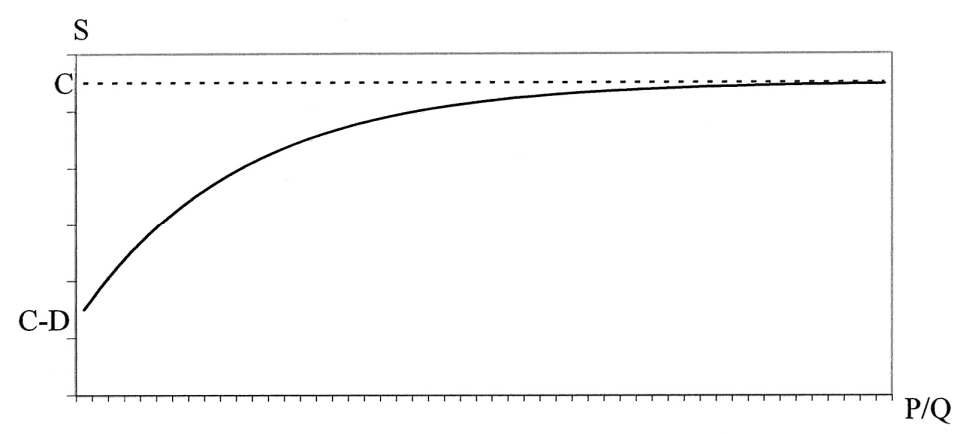

Fig 2. Example of functional control of the average wage 


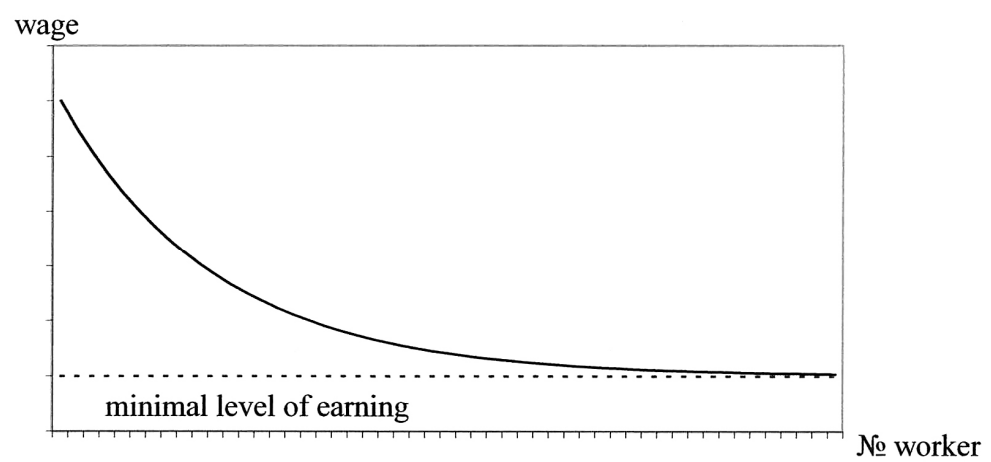

Fig 3. Example of functional control of the wage

However, it was impossible to register these inventions as scientific discoveries under the conditions of the planned economy. If these inventions had been accepted, they would have brought huge profit.

\section{References}

1. Трапезников В.А. Автоматическое управление и его экономическая эффективность. Наука и жизнь. - Nr. 11 (1965), С. 44-57.

2. Кухтенко А.И. Об аксиоматическом построении математической теории систем. Кибернетика и вычислительная техника. - Nr. 31 (1976), С. 325.

\section{Aloizs Ratnieks. Ekonomikas funkcionālā vadība}

Noskaidrota iepriekš nezināmā adaptējošo sistēmu īpašība, ka tās var vadīt nezinot informāciju par to stāvokli. Ir jāzina tikai adaptējošās sistēmas elementu dažas īpašības. Noskaidrots, ka ekonomiskām vadības metodēm ir ierobežotas iespējas. Ar to palīdzību nav iespējams regulēt visus tos ekonomiskās sistēmas parametrus, kas nepiedalās apmaiņas procesā. Piedāvāta cita, vispārēja ekonomisko sistēmu vadības metode, kas dod iespēju atdalīt ekonomiskās sistēmas vadību no ražošanas attiecībām, paplašināt matemātikas pielietošanu vadības jomā un aizvietot ievērojamu vadības aparāta un normatīvo aktu daḷu ar vienu funkcionālo attiecību. Ekonomiskas vadības metodes ir šīs metodes atseviškss gadījums.

Алоизс Ратниекс. Функциональное управление экономикой Установлено неизвестное ранее свойство адаптирующихся систем, заключающееся в том, что адаптирующейся системой можно управлять, не имея информации о ее состоянии. Необходимо иметь только некоторые характеристики ее элементов. Выяснено, что экономические методы управления имеют ограниченные возможности. С их помощью невозможно регулировать все те параметры экономической системы, которые не участвуют в процессе обмена. Предложен другой, более общий метод управления, позволяющий отделить управление экономикой от производственных отношений, расширить область применения математики в сфере управления и заменить значительную часть административно- бюрократического аппарата и нормативных актов одной функциональной зависимостью. Экономические методы управления являются частным случаем предлагаемого метода. 